\title{
A model of acute infectious neonatal diarrhoea
}

\author{
P. M. NEWSOME, M. N. BURGESS*t, MADELAINE R. BURGESS*, K. A. CONEY*, \\ M. E. GODDARD* and J. A. MORRIS $¥$
}

\begin{abstract}
Beecham Pharmaceuticals Research Divisions, Biosciences Research Centre, Great Burgh, Yew Tree Bottom Road, Epsom, Surrey KT18 $5 X \mathrm{X}$ and *Animal Health Research Centre, Walton Oaks, Dorking Road, Tadworth, Surrey KT20 7NT, and $\ddagger$ Central Veterinary Laboratory, New Haw, Weybridge, Surrey KT15 $3 N B$
\end{abstract}

Summary. Oral inoculation of neonatal MFI mice with enterotoxigenic strains of
Escherichia coli that possessed the K99 or F41 antigen or both resulted in severe
diarrhoea with high mortality. The diarrhoea was associated with increased fluid in the
gut, greatly increased numbers of $E$. coli in gut homogenates and reduced weight gain
compared to control animals. Further studies with strain B44 demonstrated greatly
increased numbers of $E$. coli on the surface of the intestinal mucosa and haemo-
concentration. The infection was transmissible between litter-mates. There was no
evidence of invasion of the intestinal tissue of infected animals. Gnotobiotic Balb C
mice and endotoxin-resistant mice were susceptible to oral inoculation with bovine
enterotoxigenic $E$. coli strains, but neonatal rats were not susceptible to infection with
enterotoxigenic $E$. coli strains B44 or 431 .
Porcine strains of $E$. coli that possessed K88 or 987 P antigen did not infect neonatal
MFI mice but an "atypical" porcine strain ( 431$)$ which possessed both K99 and F41
antigens caused diarrhoea and a high mortality. The disease in neonatal mice
resembled acute diarrhoea caused by these bacteria in other species, particularly the
calf, and the model should be of value in assessing the efficacy of therapeutic agents.

\section{Introduction}

Acute infectious diarrhoea can cause considerable mortality in man and in domestic animals (House, 1978; WHO Report, 1983). Strains of Escherichia coli require two plasmid-mediated characteristics in order to cause the disease: (i) they must adhere to the small intestine of their host; and (ii) they must produce at least one enterotoxin (LT, $\mathrm{ST}_{\mathrm{A}}$ or $\mathrm{ST}_{\mathrm{B}}$ ) that stimulates fluid secretion from the small intestine of their host (Smith and Halls, 1967; Gyles and Barnum, 1969; Burgess et al., 1978).

Bacterial attachment to the small intestinal epithelium is usually mediated by the production of adhesins on the surface of the bacteria. Antigenically distinct fimbriae (pili) have been described from human, bovine and porcine strains of $E$. coli (Ørskov and Ørskov, 1966; Evans et al., 1975; Ørskov et al., 1975; Nagy et al., 1976; Morris et al., 1982). Such fimbriae show considerable host specificity in their attachment to mucosal surfaces and this fact, together with differences in the secretory

Received 21 Mar. 1985; revised version accepted 18 Oct. 1985. $\dagger$ Correspondence should be sent to: Dr M. N. Burgess, Beecham Pharmaceuticals Research Division, Animal Health Research Centre, Walton Oaks, Dorking Road, Tadworth, Surrey K20 7NT. response of different species to the various enterotoxins produced limits the ability of $E$. coli strains to cause diarrhoeal infections in species which are not their normal host (Smith and Halls, 1967; Burgess $e t$ al., 1978; Smith and Huggins, 1978).

In order to investigate the pathogenesis of the disease and to evaluate anti-diarrhoeal therapies, several approaches have been adopted. Infections have been established in surgically-prepared or colostrum-deprived animals in which the need for bacterial attachment is reduced or the susceptibility of the animal increased (Smith and Halls, 1967; Bywater, 1977). Castor oil has been used but this agent causes histological changes in the large bowel which are not characteristic of enterotoxigenic bacterial infections (Niemegeers et al., 1976). Various authors have studied the effects of sterile enterotoxins on intestinal fluid secretion either in vivo in animals such as neonatal mice, or in vitro with perfused sheets of tissue (Field et al., 1980). However, such models do not permit study of all the interactions between bacterium and host and are of limited use for the evaluation of anti-diarrhoeal agents. For these reasons, an infection of rodents that resembled diarrhoeal infection of larger animals and man would be of considerable benefit.

Although Mushin and Dubos (1965) described an 
experimental diarrhoeal infection of young mice given a human strain of $E$. coli by mouth, few successful attempts to establish such infections have been reported (Mushin and Dubos, 1965; Davidson and Hirsch, 1975). Duchet-Suchaux (1980) found that three strains which were originally isolated from diarrhoeic calves caused diarrhoea and mortality in infant mice. However a strain of $E$. coli to which the enterotoxin and K99 plasmids had been donated failed to cause disease, whilst a strain lacking K88 and K99 retained its virulence in mice (Duchet-Suchaux, 1980; Bertin, 1983).

This paper reports the pathophysiological response of neonatal mice to oral inoculation with bovine and porcine enterotoxigenic $E$. coli strains with a view to developing a model of acute diarrhoea in laboratory animals.

\section{Materials and methods}

\section{Bacteria}

E. coli strains P16, P155, P307, Abbotstown and 431 were obtained from Dr H.W. Smith (Houghton Poultry Research Station, Huntingdonshire, England); strains HM 1676, HM 1706 and HM 1751 were from Dr H. Moon, National Animal Diseases Centre, US Department of Agriculture, Ames, 50010, USA; strains B41, B41M, B44 and B117 were originally isolated at the Central Veterinary Laboratories (CVL), Weybridge. The identity of the strains was confirmed with specific antisera before use. Strains were maintained on Dorset egg slopes, stored at $4{ }^{\circ} \mathrm{C}$ in the dark and sub-cultured every 12 months.

E. coli strains were streaked from Dorset egg slopes on to sheep-blood-agar plates and incubated for $24 \mathrm{~h}$ at $37^{\circ} \mathrm{C}$. A loop from a confluent streak was then used to inoculate a Tryptone Soya Agar (Oxoid) slope which was then incubated for $24 \mathrm{~h}$ at $37^{\circ} \mathrm{C}$. The bacteria were washed off this slope with $5 \mathrm{ml}$ of sterile phosphate-buffered saline (PBS) and used to inoculate mice in those experiments where different strains of $E$. coli were compared. A suspension of $E$. coli B44 (O9:K30, K99, F41) was prepared in this way and sterile dimethyl sulphoxide was added to a final concentration of $10 \% \mathrm{v} / \mathrm{v}$. The culture was dispensed aseptically in $500-\mu 1$ portions and rapidly frozen in liquid nitrogen. These portions were used for experiments in which the size of inoculum or the strain of mouse was studied. The viable count of all $E$. coli suspensions was measured at the time of inoculation by use of a spiral plater (Spiral Systems Inc., 6740 Cloughpike, Cincinnati, OH, USA) with TSA plates.

\section{Animals}

$\mathrm{Balb} / \mathrm{C}, \mathrm{C} 3 \mathrm{H} / \mathrm{HeJ}-\mathrm{Ips}^{\mathrm{d}}$ and some MFI mice used for comparative purposes were obtained from Olac Laboratories (Blackthorn, Oxon). Balb C mice were derived from hysterectomy-derived stock housed in sterilised isolator units both before and during experimentation. $\mathrm{C} 3 \mathrm{H} / \mathrm{HeJ}$ $\mathrm{lps}^{\mathrm{d}}$ mice were derived from previously described endotoxin-resistant animals (Kelly and Watson, 1977). Unless otherwise stated MFI mice were either supplied by D. Smith (Warlingham, Surrey) or bred from similar stock at this establishment. All mice were maintained with their mothers throughout the experiment and surgical gloves were worn to reduce the stress of handling.

\section{Infection of neonatal mice and rats}

Bacterial suspensions in PBS were prepared from TSA slopes and $50 \mu \mathrm{l}$ were administered orally into the oesophagus of each test mouse with a blunt 23-gauge needle. Controls received $50 \mu \mathrm{l}$ of sterile PBS. One-dayold rats were given $200 \mu \mathrm{l}$ of bacterial suspension. Parenteral infection was initiated by injecting $50 \mu \mathrm{l}$ of bacterial suspension subcutaneously into the loose skin behind the neck. Infected animals were observed daily and mortality was recorded. Some litters were observed more closely to measure bacterial counts, gut weight/ bodyweight ratios and haematocrit values of animals killed in extremis. Blood samples for haematocrit were obtained by decapitation. For other measurements, the whole of the intestinal tract excluding the stomach was excised and weighed, as was the remaining body. The intestine was homogenised in nine times its weight of PBS and bacterial counts (colony-forming units, cfu) were made with a spiral plater on TSA agar. Healthy control mice were killed at the same times and treated similarly.

\section{Histological examination}

Animals were killed by cervical dislocation. Tissues for light microscopy were fixed in $10 \%$ buffered formol saline $(p \mathrm{H} \mathrm{7.0)}$ before mounting in Gurr's "Paramat" wax. Sections $(4-5 \mu \mathrm{m})$ were cut and stained with haematoxylin and eosin. Tissue for scanning electronmicroscopy was prepared by the method of Malick et al. (1975) and viewed with a Philips SEM 501 scanning electronmicroscope. Tissue sections for transmission electronmicroscopy were stained with $1 \%$ aqueous uranyl acetate and lead citrate (Reynolds, 1963) and viewed with a Philips EM 300 transmission electronmicroscope.

\section{Statistics}

Statistical analysis of mortality data was performed with reference to tables by Finney et al. (1963) which provide exact significance levels appropriate to $2 \times 2$ contingency table data. Statistical analysis of weight gain data was performed by Dunnett's procedure (Steel and Torrie, 1980) for multiple comparisons. All other analysis was performed with Student's independent $t$ test.

\section{Results}

Virulence of E. coli in mice

A significant difference was observed between the 
Table. Mortality, fluid accumulation and counts of $E$. coli in infected mice

\begin{tabular}{|c|c|c|c|c|c|}
\hline Strains & $\mathrm{O} \& \mathrm{~K}$ antigens & Adhesins & $\begin{array}{c}\text { Percentage } \\
\text { mortality } \\
\text { (number of mice) }\end{array}$ & $\begin{array}{c}\text { Fluid accumulation } \\
\text { (gut weight/body weight) } \\
\pm \text { SEM }^{*}\end{array}$ & $\begin{array}{c}\text { E. coli count } \\
\text { (cfu/g wet tissue)* }\end{array}$ \\
\hline Control (PBS) & & & $0(72)$ & $0.060 \pm 0.002(12)$ & $2.1 \times 10^{6}(9)$ \\
\hline P16 & O9:K103, 987P & $987 \mathrm{P}$ & 2) & $0.004(3)$ & $1.7 \times 10^{6}(3)$ \\
\hline P307 & O8:K87, K88ab & K88 & $0(12)$ & $0.061 \pm 0.001$ (3) & $2.7 \times 10^{6}(3)$ \\
\hline Abbotstown & O149:K91, K88ac & $\mathrm{K} 88$ & $0(12)$ & $0.059 \pm 0.003(3)$ & $2.0 \times 10^{6}(3)$ \\
\hline P155 & O149:K91, K88ac & K88 & $0(12)$ & $0.062 \pm 0.002(3)$ & $1.1 \times 10^{6}(3)$ \\
\hline B117 & O9:K85, K99 & K99 & $42(46) \dagger$ & 0.089 & Not measured \\
\hline B44 & O9:K30, K99, F41 & K99, F41 & $78(60) \dagger$ & $0.090 \pm 0.004(21) \dagger$ & $6.6 \times 10^{9}(19) \dagger$ \\
\hline B44 (non-mucoid) & O9: K99, F41 & K99, F41 & $17(48) \dagger$ & 0.090 & $5.6 \times 10^{8}(1)$ \\
\hline 431 & O101:K30, K99, F41 & K99, F41 & $72(48) \dagger$ & $0.098 \pm 0.006(7) \dagger$ & $3.7 \times 10^{9}(7) \dagger$ \\
\hline B41 & O101:K99, F41 & K99, F41 & $68(36)^{\dagger}$ & $0.097 \pm 0.009(6)^{\dagger}$ & $1.2 \times 10^{9}(6) \dagger$ \\
\hline B41 mutant & O101:F4I & F41 & $42(48) \dagger$ & $0.085 \pm 0.005(3) \dagger$ & $2.3 \times 10^{9}(3) \dagger$ \\
\hline HM 1706 & $\mathrm{O} 101: \mathrm{K} 30, \mathrm{~F} 41$ & F41 & $78(45) \dagger$ & $0.096 \pm 0.003(11) \dagger$ & $7.2 \times 10^{9}(11) \dagger$ \\
\hline HM 1676 & O101:K30, F41 & F41 & $37(46) \dagger$ & $0.111 \pm 0.010(5) \dagger$ & $1.6 \times 10^{10}(5) \dagger$ \\
\hline HM 1751 & $\mathrm{O} 101: \mathrm{K} 27, \mathrm{~F} 41$ & F41 & $35(48) \dagger$ & $0.103 \pm 0.011(5) \dagger$ & $1.9 \times 10^{10}(5) \dagger$ \\
\hline
\end{tabular}

* Animals killed in extremis except for controls and experiments with strains P16, P307, Abbotstown and P155 when animals were killed for comparison. E. coli counts represent the geometric mean values that were used for statistical analysis.

$\dagger$ Significantly different from control animals $(\mathrm{p}<0.05$ or $\mathrm{p}<0.001)$ by Student's $t$ or $2 \times 2$ contingency test.

responses of MFI mice aged 4 days challenged with bovine or porcine strains of $E$. coli (table). Enterotoxigenic porcine strains P307, P16, P155 and Abbotstown (10 7 -cfu dose) all failed to kill the mice. There was no reduction in normal weight gain and at necropsy gut coliform counts of $10^{6} \mathrm{cfu} / \mathrm{g}$ of wet tissue were similar to those observed in uninfected controls. In contrast, five strains isolated from calves caused high mortality associated with diarrhoea and dehydration. Strain 431 , which is an atypical porcine strain and resembles calf strains in its pathogenicity for young piglets (Smith and Linggood, 1972), also caused high mortality in mice.

E. coli strains which lacked the K99 adhesin but produced the F41 adhesin caused disease similar to that caused by $\mathrm{K}^{+} 9^{+}$strains in mice. This group included the " $3 \mathrm{P}^{-}$" strains (HM1706, HM 1676 and HM 1751) originally isolated from piglets by Moon et al. (1980) and the B41 mutant of a bovine strain, previously described by Morris et al. (1982). F41 ${ }^{+}$,

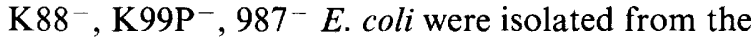
intestines of mice infected with each of these strains.

A strain of B44 (B44 non-mucoid) which lacked the $\mathrm{K} 30$ antigen was less virulent than the B44 reference strain suggesting that this antigen played a role in the infection of mice.

Signs. Infected mice passed frequent liquid stools and some animals had faecal material around their anus. Before death, the animals appeared dehy- drated, cyanosed and anoxic. Infected animals showed a statistically significant reduction in weight gain (fig. 1), accumulation of fluid in the intestine resulting in a significantly increased gut weight:bodyweight ratio, and greatly increased numbers of $E$. coli in the intestine (table). The effect upon haematocrit was determined for strain B44 and a significantly increased haematocrit value was observed $(52 \pm 2$, control value $34 \pm 1 ; \mathrm{p}<0.001$, Student's $t$ test).

Microscopy. Sections of ileum from mice infected with $E$. coli strain B44 showed large numbers of bacteria in close association with the length of the villi but no signs of tissue invasion or damage (fig. 2B). Gram-stained sections confirmed that the bacteria were gram-negative. Control sections (fig. 2A) showed no evidence of bacteria on the mucosal surface. The differences observed between micrographs of infected and control mice were consistent with the differences in bacterial counts of homogenised intestine from infected and control animals.

In sections examined by scanning electronmicroscopy there was no detectable increase in the numbers of bacteria present as the disease progressed; in all cases large numbers of bacteria were attached to the epithelium with no evidence of tissue damage (fig. 3). In contrast, no evidence of bacterial colonisation was observed in scanning electronmicrographs prepared from control animals.

Fig. 4 demonstrates the close proximity of the 


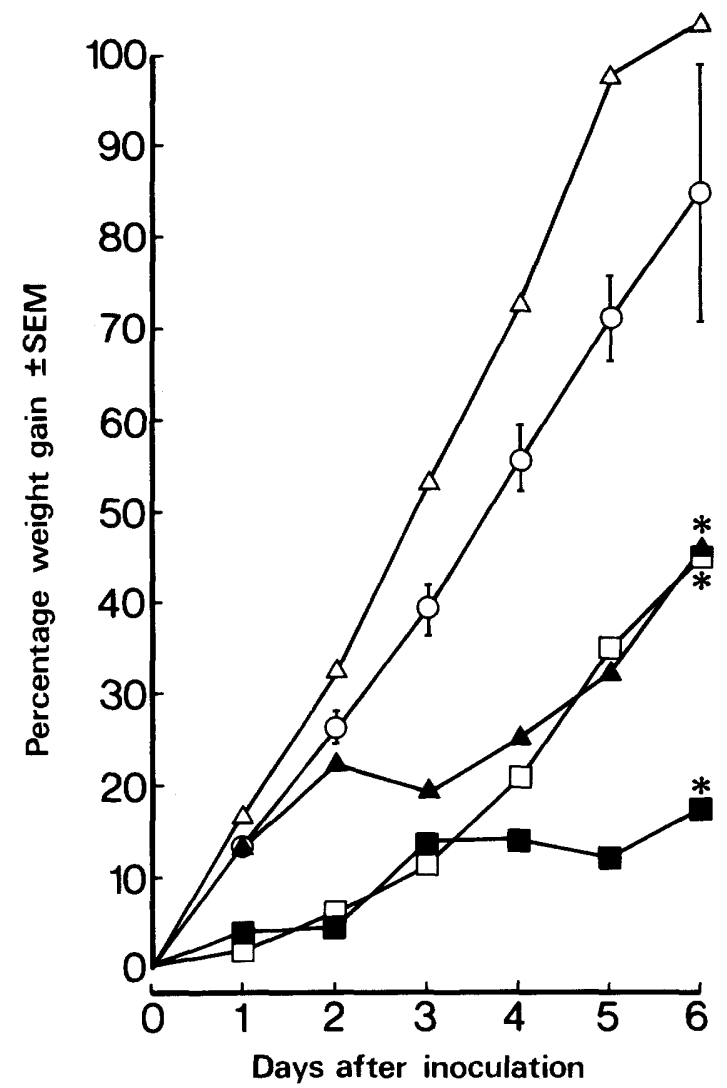

Fig. 1. Effect of E. coli strains B44, HM 1676 and P16 on weight gain after oral administration to MFI mice. Each group consisted of 12-72 mice: $O=$ uninfected controls; $\Delta=10^{5} \mathrm{cfu}$ of E. coli $\mathrm{B} 44 ; \mathbf{D}=10^{7} \mathrm{cfu}$ of $E$. coli $\mathrm{B} 44 ; \Delta=10^{7}$ cfu of $E$. coli $\mathrm{P} 16$; $\square=10^{7}$ cfu of $E$. coli HM 1676. Weight gains that were significantly different from controls $(p<0.01$, Dunnett's procedure) are indicated*.

bacteria with microvilli and the lack of any tissue damage at the point of bacterial adhesion. Several protrusions from the bacteria can be seen with some evidence of contact with the micro-villus.

Comparison of oral and parenteral routes of infection. A significantly greater mortality was observed in those animals which received $E$. coli strain B44 orally compared with the parenteral route (fig. 5; p $<0.002$ for a $10^{5}$-cfu dose orally compared with $10^{6} \mathrm{cfu}$ parenterally; $2 \times 2$ contingency). Animals which did become infected by parenteral challenge showed signs of diarrhoeal disease similar to those in animals infected orally.

Susceptibility of $\mathrm{C} 3 \mathrm{H} / \mathrm{HeJ}-\mathrm{lps}^{d}$ (endotoxinresistant) Balb/C and MFI mouse strains to infection. To investigate whether the escape of bacterial endotoxin from the intestine contributed to the disease, an experiment was performed in $\mathrm{C} 3 \mathrm{H} / \mathrm{HeJ}-$ $\operatorname{lps}^{\mathrm{d}}$ mice. These mice proved to be susceptible to infection with $E$. coli strain B44 (fig. 6), in contrast to their reported resistance to salmonella infection (Plant and Glynn, 1976). Outbred MFI mice obtained from three suppliers showed some variation in their sensitivity to infection with $E$. coli strain B44 (fig. 6). Gnotobiotic Balb C mice showed a mortality rate similar to that of some strains of conventionally reared mice.

\section{Infection of neonatal rats with $E$. coli}

No signs of disease were seen when two groups, each of four litters of rats aged 1 day, were challenged with $2 \times 10^{6} \mathrm{cfu}$ of $E$. coli strain B44 or $2 \times 10^{8}$ cfu of $E$. coli strain 431 orally. E. coli B44, $10^{3} \mathrm{cfu}$, caused $100 \%$ mortality in MFI mice aged 1 day.

\section{Mouse to mouse transmission of infection}

Examination of the cumulative mortality curves for litters of mice all challenged with $10^{5} \mathrm{cfu}$ of $E$. coli strain B44 frequently revealed the presence of two peaks of mortality at about 2 and 6 days after infection. This suggested the possibility of mouse to mouse transmission of the infection. To clarify whether mouse-to-mouse infection was taking place, the effect of challenging half of each litter with $E$. coli was examined (fig. 7). The uninfected mice showed an initial delay in the onset of diarrhoea and death but then succumbed to the diarrhoeal infection providing clear evidence of mouse-to-mouse transfer of infection between mice in the same litter. It was found practicable to avoid cross-infection between litters held in the same animal house by handling all mice with sterile surgical gloves and maintaining good animal housing procedures.

\section{Discussion}

The experiments described in this report clearly confirm the susceptibility of three strains of mice to enterotoxigenic $E$. coli isolates from calves. This finding confirms the reports of Duchet-Suchaux (1980) and Bertin (1983).

The primary role of $E$. coli as a pathogen in mice was confirmed by the ability of strain B44 to infect gnotobiotic Balb $\mathrm{C}$ mice. In our hands porcine strains of $E$. coli carrying either $\mathrm{K} 88 \mathrm{ab}$ or $\mathrm{K} 88 \mathrm{ac}$ fimbriae failed to infect mice aged 4 days. This finding is in contrast to the report of Bertin (1983) who found that two K88 ac-producing strains (P2200 and P5148) were mildly pathogenic for mice. 

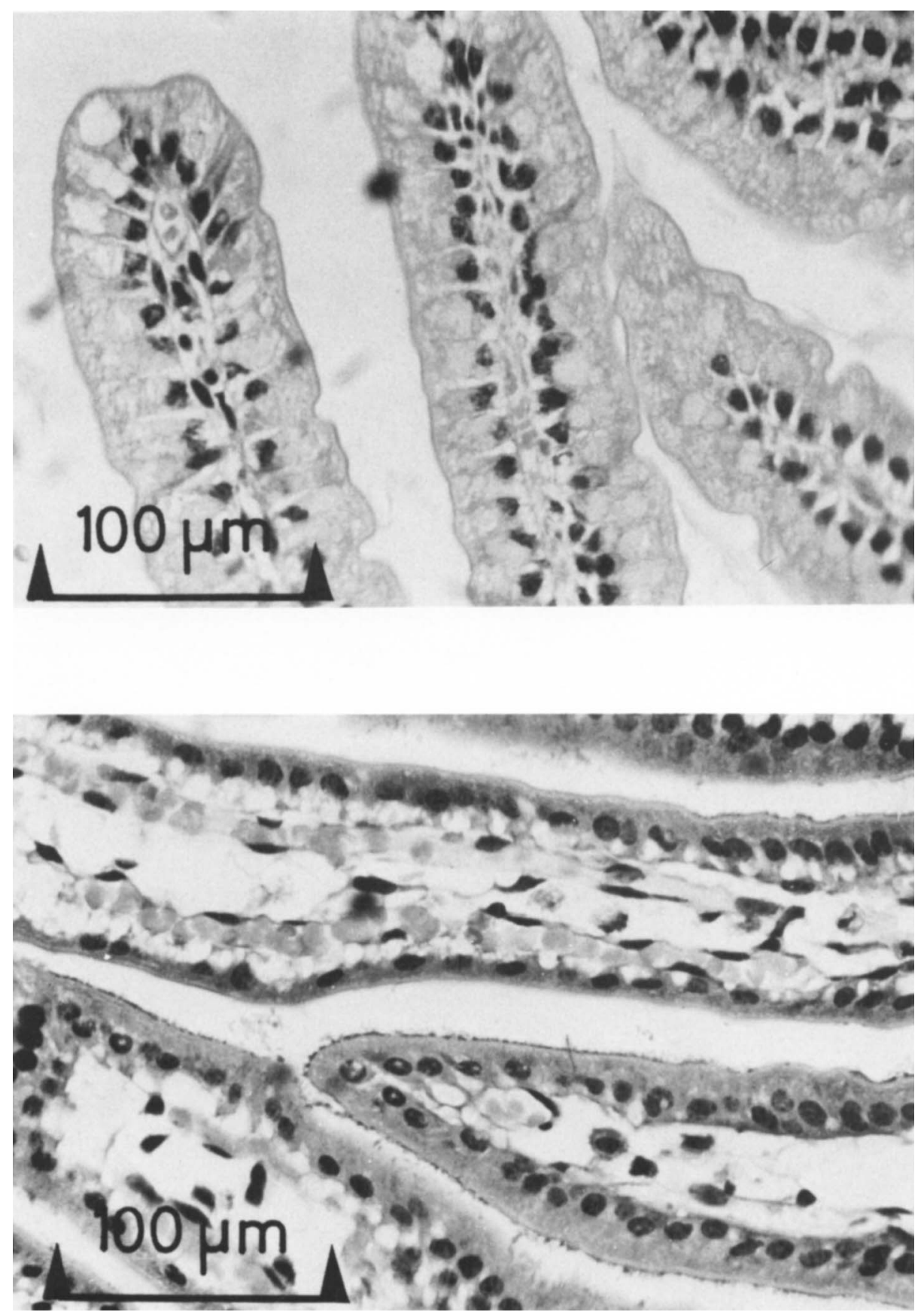

Fig. 2. Light micrographs of mouse intestinal villi: (A) from an uninfected animal and (B) from an animal infected with $E$. coli strain B44. 

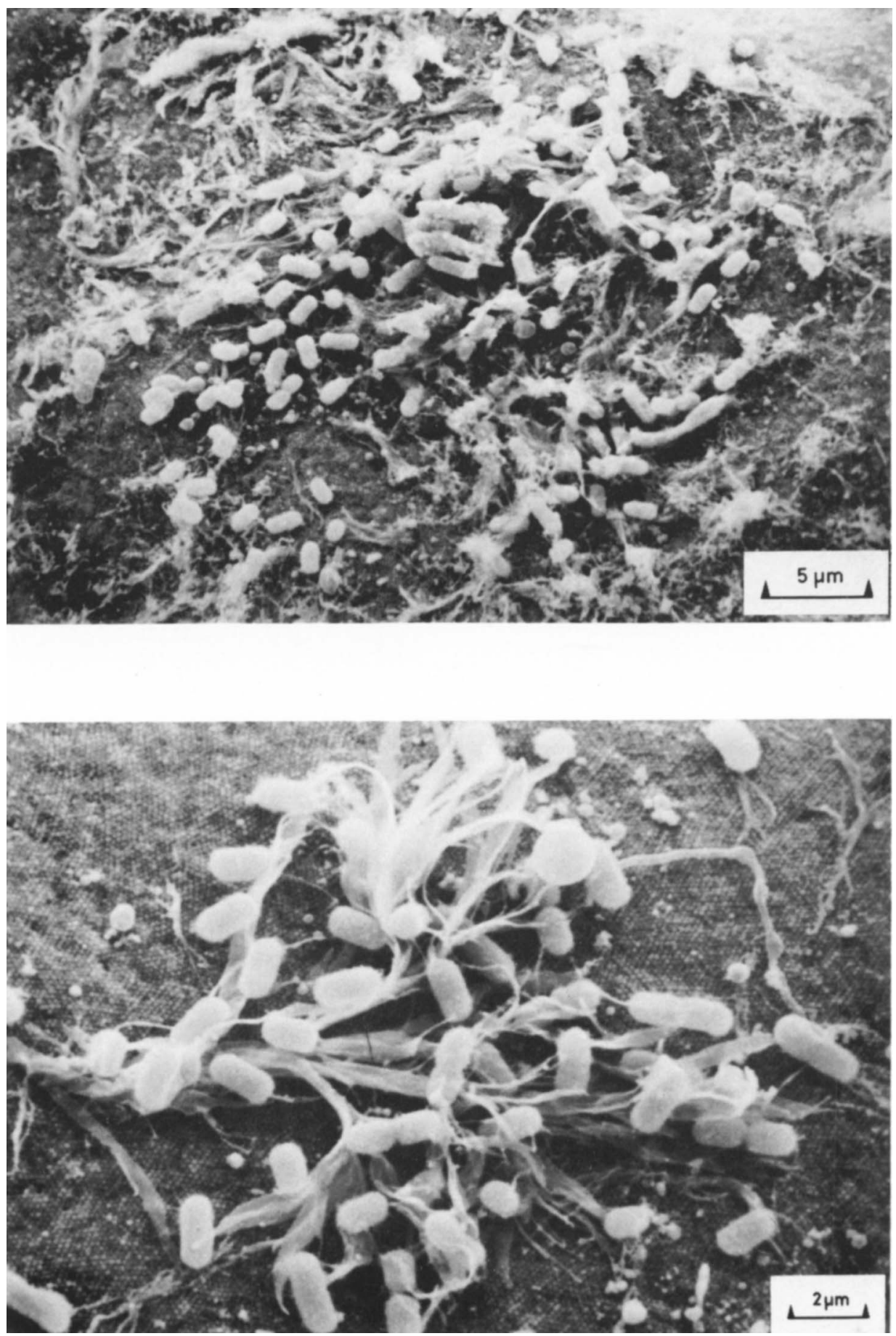

Fig. 3. Scanning electronmicrographs showing association of bacteria with the ileal brush border: (A) from a diarrhoeic animal and (B) from a moribund animal; each was infected with $10^{5} \mathrm{cfu}$ of $E$. coli strain B44. 


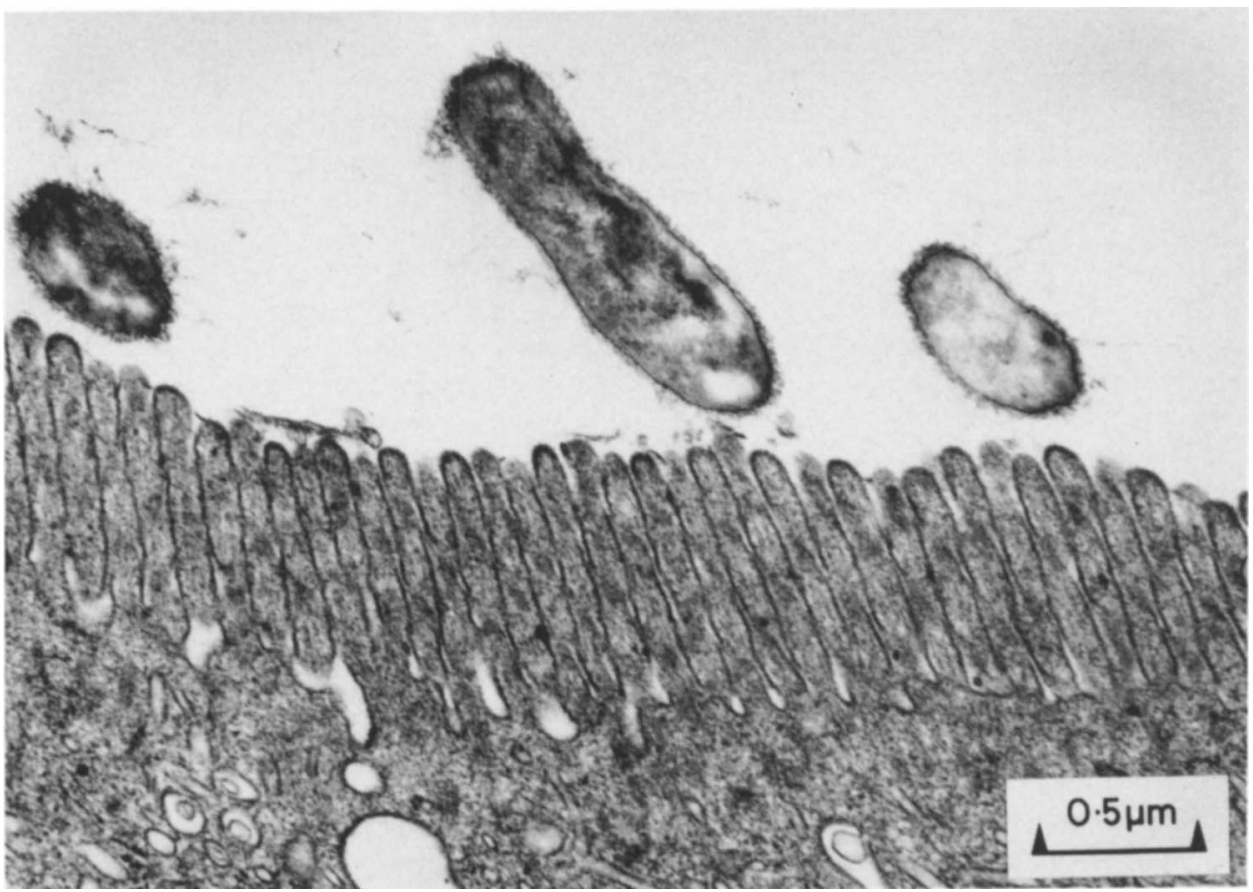

Fig. 4. Transmission electronmicrograph of the ileal brush border from a mouse infected with $10^{5} \mathrm{cfu}$ of $E$. coli strain B44.
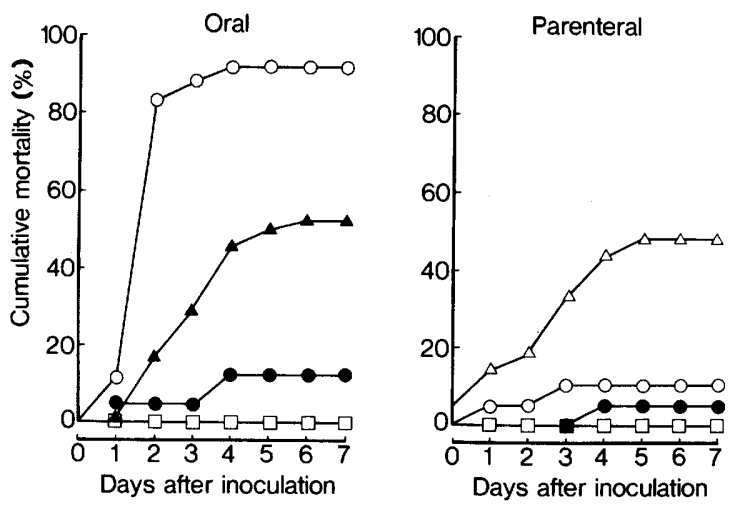

Fig. 5. Comparison of the effects of inoculating groups of Olac MFI mice with varying numbers of $E$. coli strain B44 by oral and parenteral routes. Each group consisted of 20-60 mice: $\square=$ Uninfected controls, $\bullet=10^{4} \mathrm{cfu}, \Delta=10^{5} \mathrm{cfu}, O=10^{6} \mathrm{cfu}$, $\Delta=10^{7} \mathrm{cfu}$.

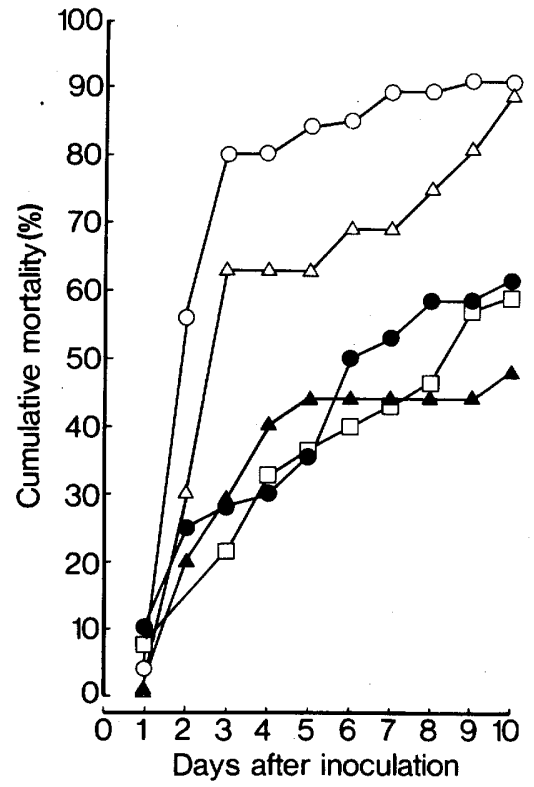

Fig. 6. Comparison of the mortality caused by $10^{\circ} \mathrm{cfu}$ of $E$. coli strain B44 in three strains and three MFI sub-strains of mice aged 4 days. Each group consisted of 25-107 mice: $O=$ MFI-(Olac); $\Delta=\mathrm{C} 3 \mathrm{H} / \mathrm{HeJ}-\mathrm{lps}^{\mathrm{d}} ; \quad \quad=$ MFI-(Smith); $\quad \square=$ MFI-(Beecham); $\Delta=$ Balb C.

Significantly higher mortality was observed in MFI-(Olac) mice than in either MFI-(Smith) or MFI-(Beecham) mice ( $p<0.01,2 \times 2$ contingency). 

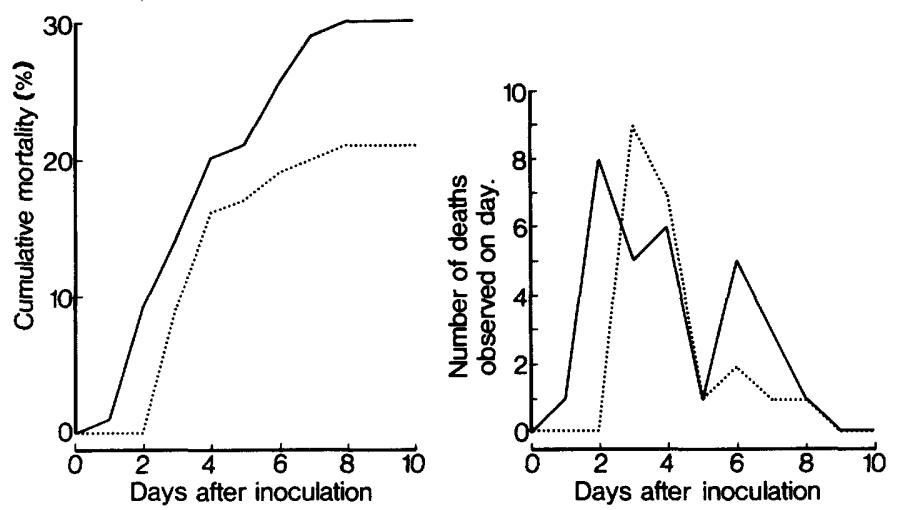

Fig. 7. Mortality resulting from the inoculation of 42 mice (six from each of seven litters) with $9.3 \times 10^{4}$ cfu of $E$. coli strain B44: $-=$ infected mice; $\ldots \ldots=$ non-infected littermates.

This difference possibly may be attributed to the use of different strains of mice or younger animals by Bertin (1983). We found that mice aged 1 day were more susceptible to infection than 4-day-old mice $\left(10^{3}\right.$ cfu of $E$. coli B 44 caused $100 \%$ mortality at 1 day of age; $p<0.05,2 \times 2$ contingency). However, we preferred to work with 4-day-old mice because, in our experience, younger mice are more susceptible to stress during handling and this factor is likely to be of particular importance if the model is used to assess therapy.

It would appear that the MFI mouse closely resembles the calf in its susceptibility to infection by K99 and F41 fimbriated $E$. coli; each of the nine strains which possessed either of the above adhesins caused mortality in MFI mice whilst none of the $\mathrm{K} 88^{+}$or $987 \mathrm{P}$ porcine strains did so $(\mathrm{p}<0.01 ; 2 \times 2$ contingency). This finding strongly suggests that the pathogenesis of the disease is similar in calves and mice. However, we were interested to test further the analogy with acute $E$. coli diarrhoea of calves.

When calves are infected by enterotoxigenic $E$. coli there is extensive colonisation of the small intestine, an increase in the number of bacteria isolated from the intestine, and attachment of numerous bacteria to an undamaged and noninflamed mucosa (Hadad and Gyles, 1982). Infected calves are dehydrated and consequently electrolyte imbalances are thought to be the cause of death. Dehydration can be demonstrated by increased haematocrit values (Fisher and de la Fuente, 1972) and is associated with loss of weight. Fisher and de la Fuente (1972) reported an increase in haematocrit from $(\%) 42 \cdot 7 \pm 8 \cdot 3$ to $51 \cdot 7 \pm 9 \cdot 8$. We have shown that mice infected with $E$. coli present a similar clinical picture. The numbers of $E$. coli isolated from the intestines of infected mice were significantly increased and comparable to those reported for calves (Smith and Halls, 1967), whilst the porcine strains failed to raise the numbers of $E$. coli in the intestine. When viewed by light microscopy or scanning or transmission electronmicroscopy, a similar picture of surface colonisation was observed, without evidence of any gross mucosal damage. Finally, infected mice showed an increase in haematocrit, a reduction in weight gain, and an accumulation of fluid in the intestine, all consistent with dehydration. The increase in gut weight/ bodyweight ratio observed in our experiments was similar to that observed after oral administration of heat-stable $E$. coli enterotoxin, except that it was observed much later in relation to oral dosing (Mullan et al., 1978). Davidson and Hirsch (1975) have previously reported similar accumulation of fluid in mouse intestine $24 \mathrm{~h}$ after giving CD-1 mice $10^{7} \mathrm{cfu}$ of porcine $E$. coli.

Invasive intestinal infections, such as those caused by Salmonella species, are well documented in calves and mice, but are generally associated with greater histological damage than we have demonstrated with $E$. coli in mice. Also, the results of our experiments with parenterally challenged mice did not support the possibility that orally challenged mice became systemically infected, because about 100 times more $E$. coli strain B44 were required to infect mice by this route. This contrasts with the report of Collins and Carter (1978) who found that Salmonella species were at least 50 times more virulent by parenteral routes. However, we felt it necessary to investigate if escape of bacteria or endotoxin from a reservoir of infection in the small intestine might cause death, since escape of endotoxin from the gut of hypovolaemic animals has been demonstrated, leading to fatal endotoxic 
shock (Gaffin et al., 1981). To test this hypothesis we used an inbred strain of $\mathrm{C} 3 \mathrm{H} / \mathrm{HeJ}-\mathrm{lps}^{\mathrm{d}}$ mice which had been shown to be resistant to endotoxin and to salmonella infection (Plant and Glynn, 1976; Kelly and Watson, 1977). These mice were as susceptible to infection with $E$. coli strain B44 as were endotoxin-sensitive strains; this result would be expected for an infection which was localised in the gut lumen without egress of bacteria or toxin.

We found evidence of transfer of infection from diarrhoeic mice to healthy mice within the same litter. Half the animals which were not given $E$. coll developed lethal infection if they were kept as littermates with infected mice. We also observed a biphasic mortality curve for mice given $E$. coli strain B44. The shape of this curve possibly may indicate that not all of the mice received a lethal dose of $E$. coli at the time of inoculation, but that some of these became re-infected or cross-infected by severely diarrhoeic litter-mates. We believe that such crossinfection should enhance the value of the $E$. coliinfected mouse as a model of calf diarrhoea because it should be possible to simultaneously assess the effects of any therapeutic measure on the primary infection and on the susceptibility to cross infection.

Like Duchet-Suchaux (1980) we found differences in the susceptibility of different in-bred and out-bred strains of mice to a single strain of $E$. coli but these variations were no larger than those which we observed between MFI mice obtained from different suppliers. Differences in the diet of pregnant females are known to affect the susceptibility of young mice to intestinal infection with rotavirus although it is questionable if these differences would be large enough to account for the differences we

\section{REFERENCES}

Bertin A 1983 Virulence factors of enterotoxigenic Escherichia coli studied in the infant mouse model. Annales de Recherches Veterinaires 14:169-182.

Burgess M N, Bywater R J, Cowley C M, Mullan N A, Newsome P M 1978 Biological evaluation of a methanol-soluble, heatstable Escherichia coli enterotoxin in infant mice, pigs, rabbits and calves. Infection and Immunity 21:526-531.

Bywater R J 1977 Evaluation of an oral glucose-glycineelectrolyte formulation and amoxicillin for treatment of diarrhea in calves. American Journal of Veterinary Research 38: 1983-1987.

Collins F M, Carter P B 1978 Growth of salmonellae in orally infected germfree mice. Infection and Immunity 21: 41-47.

Davidson J N, Hirsh D C 1975 Use of the K88 antigen for in vivo bacterial competition with porcine strains of enteropathogenic Escherichia coli. Infection and Immunity 12:134-136.

Duchet-Suchaux M 1980 Le souriceau, modèle d'étude de la diarrhée colibacillaire. Annales de Microbiologie (Institut Pasteur) 131B:239-250. observed (Noble et al., 1983). Since all three MFI colonies were conventionally maintained, differences in their intestinal flora at the time of inoculation might be of greater significance than diet (Newsome and Coney, 1985).

The present work has provided further evidence for the importance of the F41 antigen as a virulence factor in enterotoxigenic $E$. coli. The role of F41 as an adhesion factor in calves was described by Morris et al. (1982), following the appearance of an adherent mutant of the reference strain B41 (B41M) lacking the K99 antigen. They demonstrated that strain B41 possessed both K99 and F41 adhesins and could lose K99 and still retain virulence. Bertin (1983) showed that another mutant of B41 (B41A), which lacked $\mathrm{K} 99$, retained virulence in neonatal mice, but he did not characterise this mutant as $\mathrm{F} 41^{+}$. Our results show that four strains of $E$. coli (including $\mathrm{B} 41 \mathrm{M}$ ), characterised previously as $\mathrm{F} 41^{+}, \mathrm{K} 9^{-}$, are all virulent in mice. We therefore conclude that F41 and K99 are alternative virulence characters for mice (as for calves) although other antigens may be involved. The reduced virulence of a non-mucoid strain of $E$. coli B44 observed in the present study suggests that the $\mathrm{K} 30$ capsular antigen may also augment virulence in the mouse. This finding is consistent with the observation in calves that antibody to the $\mathrm{K} 30$ antigen reduces calf mortality (Myers, 1978).

We thank Mr J. Warrack and Mr C. Blackmore for the preparation and photography of light and electron micrographs; Miss L. Bannister for her capable technical assistance; Mr J. Habkirk and Mr D. Hiley for breeding MFI mice; and Mrs J. Buckley for her excellent secretarial services.

Evans D G, Silver R P, Evans D J, Chase D G, Gorbach S L 1975 Plasmid-controlled colonization factor associated with virulence in Escherichia coli enterotoxigenic for humans. Infection and Immunity 12:656-667.

Field M, Fordtran J S, Schultz S G (eds) 1980 Secretory diarrhea. American Physiological Society, Baltimore, MD, USA.

Finney D J, Latscha R, Bennett B M, Hsu P (1963) Tables for testing significance in a $2 \times 2$ contingency table. Cambridge University Press, Cambridge.

Fisher E W, de la Fuente G H 1972 Water and electrolyte studies in newborn calves with particular reference to the effects of diarrhoea. Research in Veterinary Science 13:315-322.

Gaffin S L, Grinberg Z, Abraham C, Birkhan J, Shechter Y 1981 Protection against hemorrhagic shock in the cat by human plasma containing endotoxin-specific antibodies. Journal of Surgical Research 31:18-21.

Gyles C L, Barnum D A 1969 A heat-labile enterotoxin from strains of Escherichia coli enteropathogenic for pigs. Journal of Infectious Diseases 120:419-426.

Hadad J J, Gyles C L 1982 Scanning and transmission electron microscopic study of the small intestine of colostrum-fed 
calves infected with selected strains of Escherichia coli. American Journal of Veterinary Research 43: 41-49.

House J A 1978 The economic impact of rotavirus and other neonatal disease agents of animals. Journal of the American Veterinary Association 173:573-576

Kelly K, Watson J 1977 The inheritance of a defective lipopolysaccharide response locus in $\mathrm{C} 3 \mathrm{H} / \mathrm{HeJ}$ mice. Immunogenetics 5:75-84.

Malick L E, Wilson R B, Stetson D 1975 Modified thiocarbohydrazide procedure for scanning electronmicroscopy: routine use for normal, pathological or experimental tissues. Stain Technology 50:265-269.

Moon H W, Kohler E M, Schneider R A, Whipp S C 1980 Prevalence of pilus antigens, enterotoxin types, and enteropathogenicity among K88-negative enterotoxigenic Escherichia coli from neonatal pigs. Infection and Immunity 27:222-230.

Morris J A, Thorns C, Scott A C, Sojka W J, Wells G A 1982 Adhesion in vitro and in vivo associated with an adhesive antigen (F41) produced by a K99 mutant of the reference strain Escherichia coli B41. Infection and Immunity 36:11461153.

Mullan N A, Burgess M N, Newsome P M 1978 Characterization of a partially purified, methanol-soluble, heat-stable Escherichia coli enterotoxin in infant mice. Infection and Immunity 19:779-784.

Mushin R, Dubos R 1965 Colonization of the mouse intestine with Escherichia coli. Journal of Experimental Medicine 122:745-757.

Myers L L 1978 Enteric colibacillosis in calves: immunogenicity and antigenicity of Escherichia coli antigens. American Journal of Veterinary Research 39:761-765.

Nagy B, Moon H W, Isaacson R E 1976 Colonization of porcine small intestine by Escherichia coli: ileal colonization and adhesion by pig enteropathogens that lack K 88 antigen and by some acapsular mutants. Infection and Immunity 13:1214-1220.

Newsome P M, Coney K A 1985 Synergistic rotavirus and Escherichia coli diarrheal infection of mice. Infection and Immunity 47:573-574.

Niemegeers C, Lenaerts F, Awouters F 1976 Preclinical animal studies of modern antidiarrhoeals. In: Van Bever W, Lal H (eds) Synthetic antidiarrhoeal drugs. (Modern Pharma-
cology-Toxicology Series, vol. 7.) Marcel Decker, New York pp 65-114.

Noble R L, Sidwell R W, Mahoney A W, Barnett B B, Spendlove R S 1983 Influence of malnutrition and alterations in dietary protein on murine rotaviral disease. Proceedings of the Society for Experimental Biology and Medicine 173:417426.

Ørskov I, Ørskov F 1966 Episome-carried surface antigen K88 of Escherichia coli. I. Transmission of the determinant of the K88 antigen and influence on the transfer of chromosomal markers. Journal of Bacteriology 91:69-75.

Ørskov I, Ørskov F, Smith H W, Sojka W J 1975 The establishment of K99, a thermolabile, transmissible Escherichia coli $\mathrm{K}$ antigen, previously called $\mathrm{Kco}$ possessed by calf and lamb enteropathogenic strains. Acta Pathologica et Microbiologica Scandinavica. Section B 83:31-36.

Plant J, Glynn A A 1976 Genetics of resistance to infection with Salmonella typhimurium in mice. Journal of Infectious Diseases 133:72-78.

Reynolds E S 1963 The use of lead citrate at high $\mathrm{pH}$ as an electron-opaque stain in electron microscopy. Journal of Cell Biology 17:208-212.

Smith H W, Halls S 1967 Observations by the ligated intestinal segment and oral inoculation methods on Escherichia coli infections in pigs, calves, lambs and rabbits. Journal of Pathology and Bacteriology 93:499-543.

Smith H W, Huggins M B 1978 The influence of plasmiddetermined and other characteristics of enteropathogenic Escherichia coli on their ability to proliferate in the alimentary tracts of piglets, calves and lambs. Journal of Medical Microbiology 11:471-492.

Smith H W, Linggood M A 1972 Further observations on Escherichia coli enterotoxins with particular regard to those produced by atypical piglet strains and by calf and lamb strains: the transmissible nature of these enterotoxins and of a $\mathrm{K}$ antigen possessed by calf and lamb strains. Journal of Medical Microbiology 5:243-250.

Steel R G D, Torri J H 1980 Principles and procedures of statistics. McGraw Hill, London.

WHO, UNICEF $1983 \mathrm{In}$ : The management of diarrhoea and use of oral rehydration therapy. A joint WHO/UNICEF Statement. World Health Organization, Geneva. 